\title{
Article \\ Comparative Study of Different Types of Waterproofing Screeds with a Focus on Cohesion with Selected Building Materials after the Freeze-Thaw Exposure
}

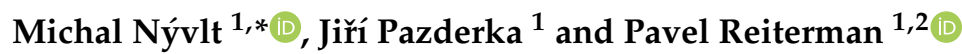 \\ 1 Faculty of Civil Engineering, Czech Technical University in Prague, Thákurova 7, \\ 16629 Prague, Czech Republic; jiri.pazderka@fsv.cvut.cz (J.P.); pavel.reiterman@fsv.cvut.cz (P.R.) \\ 2 University Centre of Energy Efficient Buildings, Czech Technical University in Prague, Třinecká 1024, \\ 27343 Buštěhrad, Czech Republic \\ * Correspondence: Michal.nyvlt@fsv.cvut.cz; Tel.: +420-739-968-855
}

Citation: Nývlt, M.; Pazderka, J.; Reiterman, P. Comparative Study of Different Types of Waterproofing Screeds with a Focus on Cohesion with Selected Building Materials after the Freeze-Thaw Exposure. Appl. Sci. 2021, 11, 11256. https://doi.org/ 10.3390/app112311256

Academic Editor: Asterios Bakolas

Received: 29 October 2021

Accepted: 24 November 2021

Published: 27 November 2021

Publisher's Note: MDPI stays neutral with regard to jurisdictional claims in published maps and institutional affiliations.

Copyright: (c) 2021 by the authors. Licensee MDPI, Basel, Switzerland. This article is an open access article distributed under the terms and conditions of the Creative Commons Attribution (CC BY) license (https:// creativecommons.org/licenses/by/ $4.0 /)$.

\begin{abstract}
The aim of the research was focused on the functionality of three types of waterproofing screeds from the perspective of their use in building structures. Bitumen, polymer, silicate (mineral) were studied in terms of their cohesion with the substrate and their sealing ability, used in combination with different building materials-ceramics, concrete, lime-sand bricks and marl stone, the permeability properties of which were taken into consideration, too. The cohesion was also studied after the freeze-thaw exposure to take into account the aspects of durability. During the experimental program, the basic waterproofing ability of all types of tested screeds applied on building materials was confirmed. Comparing the overall tested screeds, despite the best adhesion of the polymer-based screed, this material exhibited the lowest durability after the freeze-thaw exposure. The bitumen and silicate (mineral) screed attained similar values of adhesion to the studied base materials. However, they differ in their ability to withstand freeze-thaw cycles over time. The modified water permeability test on model masonry specimens was performed. No leakage of water during the test was monitored for the specimens with all types of applied screeds over time, and, in addition, water had not penetrated through the bricks, nor through the joints. The waterproofing effect of the screed is not affected by the joints in masonry.
\end{abstract}

Keywords: waterproofing screeds; freeze-thaw cycles; adhesion; building structures

\section{Introduction}

Waterproofing screeds are a common way of protecting structures against the ingress of water to enhance their durability. The commonly used screed has a number of proper applications in building structures (basements, balconies, wet rooms) [1-3] as well as in civil engineering (water reservoirs, bridges [4,5]), tunnels [6]).

According to national standards, waterproofing screeds are defined as waterproofing compounds resistant to water, which are applied to an insulated structure by painting, trowelling or cold or hot spraying under specific conditions. After the on-site application, they form seamless screed waterproofing.

Waterproofing screeds can be divided into three groups according to the material composition. The first group are waterproofing screeds based on bitumen (bitumen varnishes, emulsions, dispersions). The second group of waterproofing screeds is based on synthetic polymers (polyurethane, epoxy, polyester, dispersion, special synthetic), and the third group is based on silicate screeds (a mixture of finely ground cement in a mixture with sand or limestone and modifiers). Alternatively, the advantages of individual groups can be used, and the above-mentioned materials can be combined.

Today, waterproofing screeds are most often used in the case of solving complex construction details in combination with other screed sheet waterproofing [7-9]. Waterproofing 
screeds are often used for their resistance to the stress of walking or moving cars. They can also be used as waterproofing with protective utility layers (balconies, terraces, roof coverings). Common applications can also be found in the use of waterproofing screeds in the remediation of moisture faults [4,9-12].

Due to the above-mentioned use of waterproofing screeds, they age during their life due to environmental influences such as: high and low temperature, sunlight (ultraviolet radiation-UV) and rainfall, causing degradation phenomena, such as frost-thawing [13]. Research [13] has confirmed significant changes in the physical and chemical properties of the selected tested building materials. The physical and chemical properties have changed. Due to frost and UV radiation, the compressive strength was reduced by at least $13 \%$. The external environment also negatively affected the adhesion of individual plasters [13]. By reducing adhesion and compressive and tensile strength, the material's ability to bridge cracks is also significantly reduced.

\subsection{Bituminous Screeds}

Bituminous screeds have evolved from the commonly and traditionally used bitumen waterproofing. Bituminous screeds as well as asphalt strips are used to insulate all surfaces of the substructure (vertical and horizontal). Like asphalt strips, they can be used as protection against ground moisture and pressurised water. The protection is, therefore, comparable.

The bituminous insulating screeds (waterproofing putty according to national standards), known in Germany under the abbreviation of KMB (Kunststoffmodifizierte Bitumendickbeschichtung) [14], have an asphalt emulsion binder.

Their sealing viscosity is enhanced by thickening with light flexible fillers (polystyrene granulate, rubber, etc.). The grain of the filler determines the thickness of the layer, and this is now specified by standards and guidelines. For the use of KMB in new constructions, the reference of DIN 18195 (08-2000) [15] applies, which requires a dry layer thickness of at least $3 \mathrm{~mm}$ for lower loads-ground moisture, unretained seeping water, non-pressurised water in damp areas and a dry layer thickness of $4 \mathrm{~mm}$ for higher loads-pressurised water and retained leaking water.

The main advantage of bituminous screeds is their long service life. Unlike asphalt strips, they do not break and do not lose flexibility (do not become brittle) [16]. We can also observe a significant effect of heat and ultraviolet aging on the structure, and the properties of styrene-butadiene-styrene (SBS) -modified bitumen for watertightness [17]. The application of a waterproofing screed creates a screed without joints, which are a very common cause of failures of the waterproofing system with asphalt strips (no joints, cuts and waste are created). The screed is, therefore, suitable as insulation for rugged surfaces and easy connection of vertical and horizontal surfaces. The sealing details can also be easily solved. With the correct design and adherence to the technological process, they adhere fully to the substrate, which can be uneven. The bituminous screed can also be used to seal joints [15].

Bituminous screeds are applied to the prepared substrate (concrete, plaster, brickwork, silicate blocks, etc.) [15]. Most often, the substrate is impregnated with a bitumen emulsion, and the mixed screed (it can be mixed mechanically or manually) is always applied in two layers [15].

According to the commonly used manufacturer's technical sheets, the first layer is applied up to a maximum of $50 \%$ of the total thickness. If protection against pressurised water is required, a reinforcing mesh is incorporated into the fresh first layer. The second layer can be applied only after the first layer has hardened.

The disadvantage of this type of screed, in general, is the complexity of the implementation (it is necessary to follow the manufacturer's technical sheet temperature, humidity, dosage, mixing speed, etc.) [15-18]. Due to their appearance, bitumen screeds are not suitable for use in visible constructions, because the surface is usually black-brown, uneven, and may be greasy. 


\subsection{Silicate (Mineral) Screeds}

Owing to the cement binder, these screeds are easy to process for a wide range of construction practices. Only a bucket for mixing the mixture and masonry tools are enough for processing.

The mineral insulating screed (a silicate waterproofing compound according to the technical standard) is listed in German-speaking countries under the abbreviation of MDS (Mineralische DichtungSchlämme) [14]. The composition is formed by micro-milled cements (often also sulphate-resistant) with mineral fillers and organic finishing additives. Its important advantage is high adhesion to mineral substrates $[19,20]$.

The screed can withstand even the negative pressure of penetrating water. This predestines it especially for insulation on the inner face of masonry, on structures inaccessible from the outside. With such a mass, it is possible to create a kind of inner tube that retains water in the structure [21]. Compared to bitumen screeds, the matrix of silicate-based screeds is more porous and remains relatively diffusely open.

The disadvantage of purely mineral screeds is the inability to bridge cracks that additionally form in the substrate - the layer of hardened screed is brittle [14].

The inability of silicate screeds to bridge cracks can be solved by adding additives, most often polymers. The addition of this additive creates a third large group of the squeegees described below.

The specific type of waterproofing system is the application of a crystalline screed, primarily used for the protection of concrete structures against water ingress. The crystalline screed can also be included in the group of the solved waterproofing materials. It has already been proven that the crystalline screed significantly increases the durability of the silicate-based structure [22,23], and is also a protective system for reinforced concrete, which prevents the corrosion of the reinforcement [24]. The specificity of the crystalline screed is its functionality only on calcium silicate materials. Therefore, crystalline screeds are not the subject of this study.

\subsection{Polymer Screeds}

By adding a polymer to the silicate mixture, a modified silicate waterproofing compound is created. In addition to micronized cements and mineral fillers, it also contains a large admixture of a plastic or elastomer dispersion [14,15].

Unfortunately, the addition of polymers impairs the adhesion to the substrate. Flexible MDS are, therefore, only used on the water pressure side, usually for the insulation of tanks, pools, and reservoirs. In cases where watertightness is necessary, the ability to bridge cracks wins. Another disadvantage of flexible MDS is the lower resistance to hot water [25].

Research methods of aging processes are based primarily on the analysis of changes in material properties based on observations in natural or artificial conditions. We get the most reliable results from long-term aging tests that have been performed for many years $[13,26]$. Nowadays the trend is to apply for durability on the basis of short-term tests. Trend is for accelerating ageing tests replacing long-term degradation processes in natural conditions. These methods are based on appropriate procedures or of a simulation origin in climate chambers [13].

The subject of the study is a laboratory analysis of the interaction of different types of waterproofing screeds with different types of building structures. The above is a description of the properties of the used waterproofing screeds with a specific focus on their cohesion of different substrate materials. More recently, the change in mechanical properties will depend on freeze-thaw cycles $[27,28]$. The currently used waterproofing screeds exhibit suitable tightness, however, the aspects reflecting their durability during their exposure to freeze-thaw cycles has not been widely studied yet. A failure of the waterproofing system could rapidly reduce the lifespan of the entire structure, and usually leads to other undesired processes in the internal environment of the building. 


\section{Materials and Methods}

The aim of the research was to determine the functionality of waterproofing screeds from the perspective of their use in building structures. Hence, the testing was focused on the mechanical and durability properties.

\subsection{Basic Study-Water Pressure Test}

In the first step, before performing the tear-off tests, it was necessary to verify the watertightness of individual waterproofing screeds (described above) on a common substrate (calcium silicate bricks).

The water pressure test was conducted at the device which allowed loading with low water pressure $(0.01 \mathrm{MPa})$ on a circular surface of $50 \mathrm{~mm}$ in diameter. The measurement was performed on calcium silicate bricks $(290 \times 140 \times 65 \mathrm{~mm})$ with applied screeds. In total, 15 specimens were prepared for the test (Figure 1) - three for each studied screed, i.e., bitumen, polymer, silicate (mineral), and three more for the reference set without any screed.

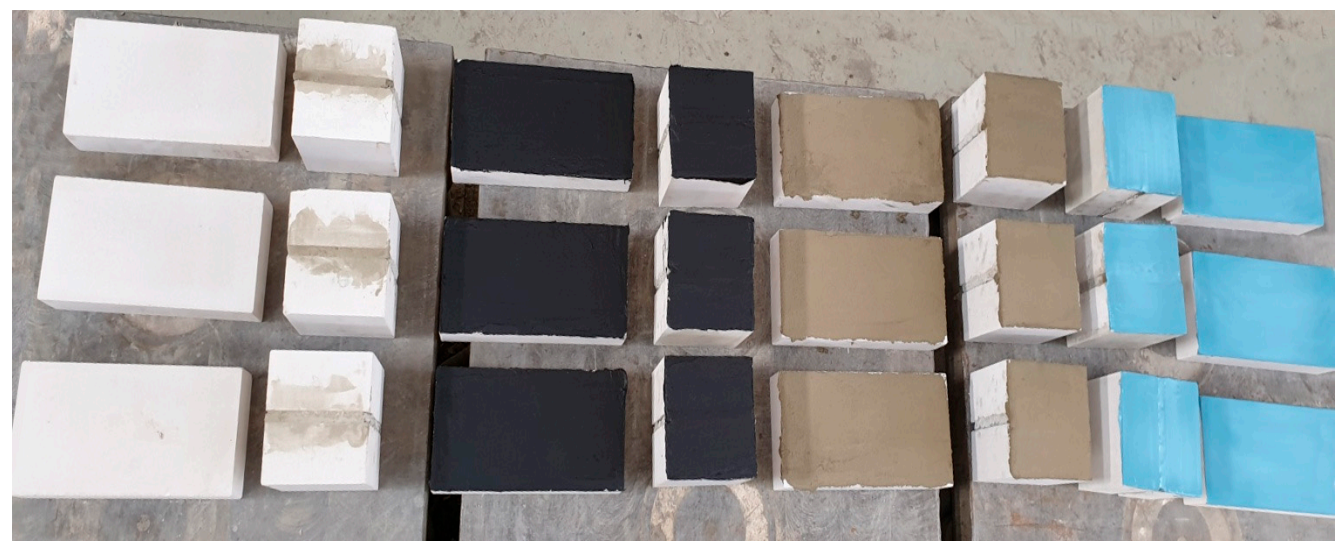

Figure 1. Test specimens.

The test was performed 20 days after the screed application. The screeds were applied to one surface of the brick according to the manufacturer's technological guide compiled for structures (for which the screed is intended).

The specimens were loaded with a water pressure of $0.06 \mathrm{MPa}$ for $5 \mathrm{~h}$ (Figure 2). The pressure of $0.06 \mathrm{MPa}$ was chosen with regard to the use of waterproofing screeds in building structures (basement walls). It corresponds to $6 \mathrm{~m}$ of a water column, i.e., approximately 2 underground floors. Five hours was chosen because it is the time at which the reference specimen was fully saturated with water and water began seeping through the material.

The water pressure was increased to $0.12 \mathrm{MPa}$ for $24 \mathrm{~h}$ after $5 \mathrm{~h}$ except the reference specimens. Subsequently, there was a last increase to $0.24 \mathrm{MPa}$, which also worked for the next $24 \mathrm{~h}$.

All water pressure tests were performed with water permeability apparatus model No. C0246/6 (Controls, Cernusco, Italy). 


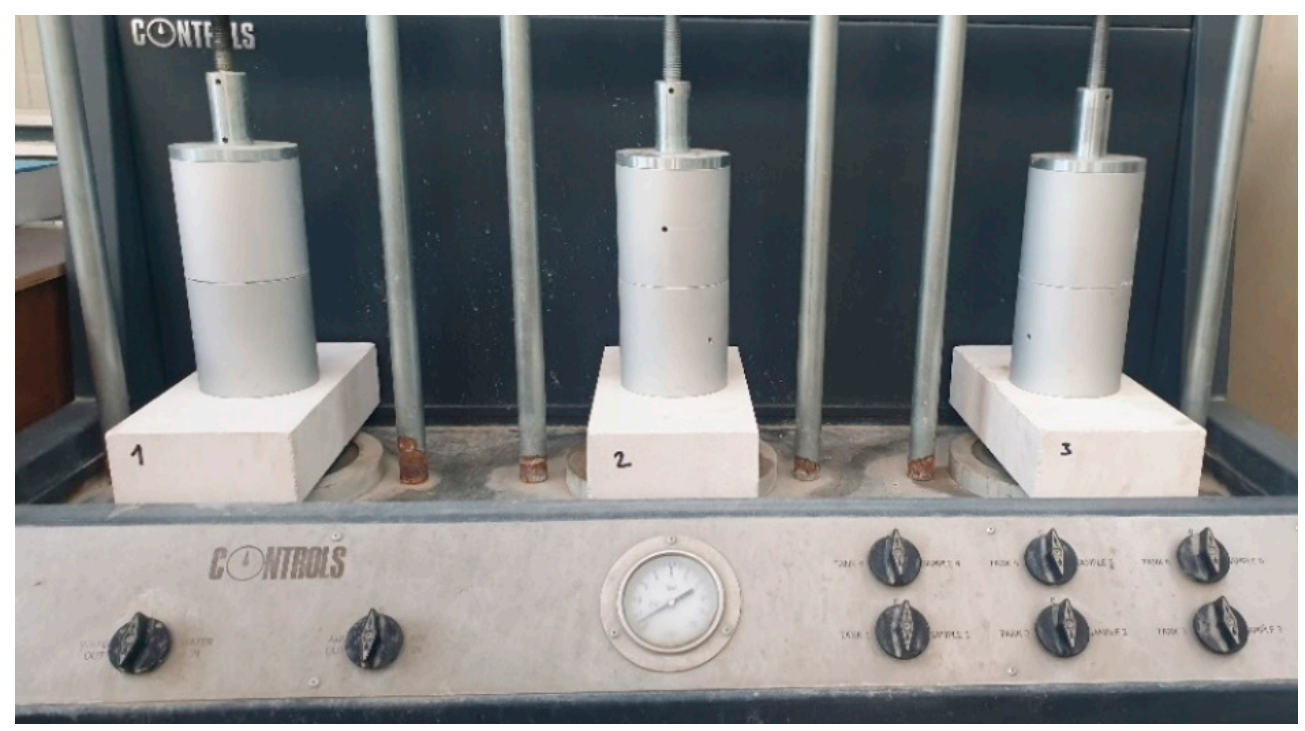

Figure 2. Water pressure test.

\subsection{Additional "Masonry Test"-Influence of Joints}

The water test on "whole masonry" specimens was a logical next step after successful results of the previous testing on separate bricks (Section 2.1). It is necessary to analyse the impact of the joints in masonry on the resulting waterproofing effect of selected screeds.

For these purposes, special test specimens - sets consisting of two bricks connected by mortar-were created. The lime-cement (mixture of cement clinker, cement dust, inorganic fillers and refining additives) mortar was used for joining the bricks. Each specimen was made up of two halves of the brick-145 $\times 140 \times 65 \mathrm{~mm}$ (the original size of the brick had been modified with respect to the dimensions of the test equipment). The overall dimensions of the test specimens were thus $145 \times 140 \times 145 \mathrm{~mm}$. For further testing, it was important to create a perfectly flat surface on which the waterproofing screeds would be further applied. That is why wooden formwork was created (Figure 3a).

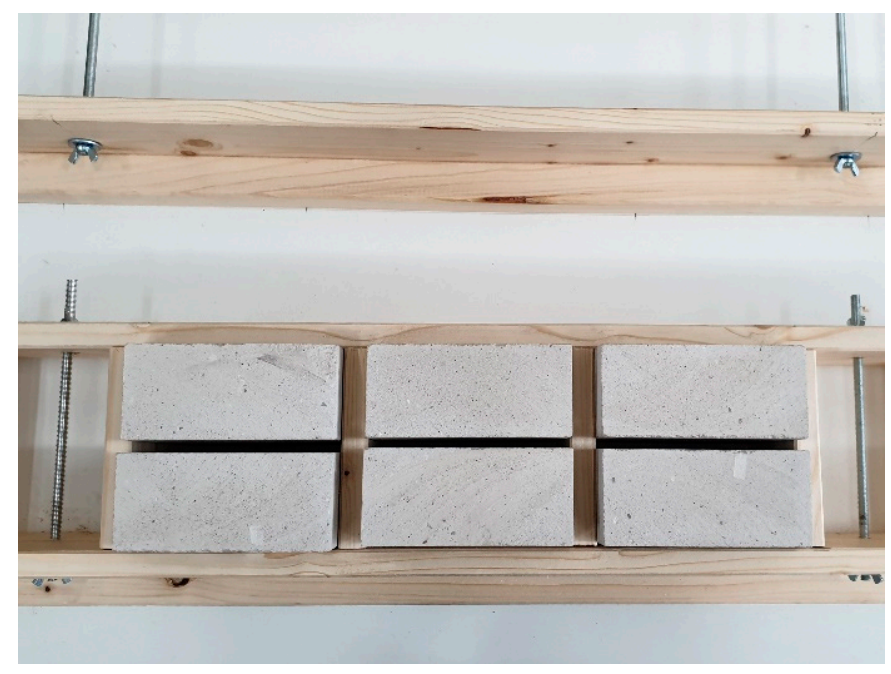

(a)

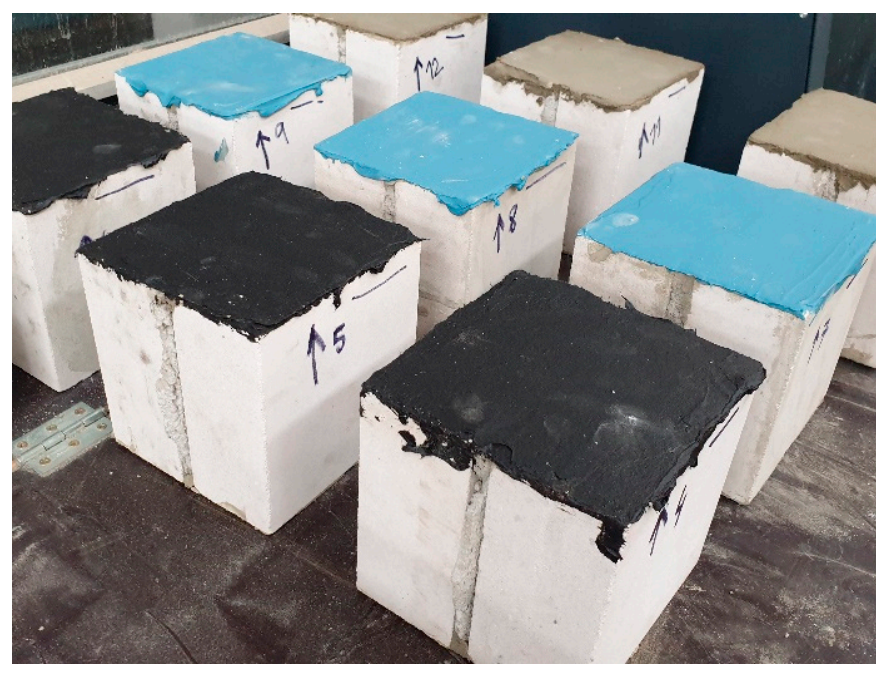

(b)

Figure 3. (a) Test specimen-lime-sand bricks and lime-cement mortal in wooden formwork; (b) test specimens with applied waterproof screeds. 
A total of 12 test sets were created-3 with the applied bitumen screed, 3 with the applied polymer screed, 3 with the applied silicate (mineral) screeds, and 3 without any treatment (reference specimen). Each of the waterproofing materials was applied to three test specimens to verify the functionality of the experiment. Another three specimens were left without a screed or screeds as reference specimens (Figure 3b).

The method of waterproofing testing (Figure 4) was almost identical with a previous case studying the individual bricks described in Section 2.1, however the maximum water pressure applied was reduced. In this case the loading regime consisted of $5 \mathrm{~h}$ of water pressure of $0.06 \mathrm{MPa}$ and following $7 \mathrm{~h}$ water pressure of $0.12 \mathrm{MPa}$.

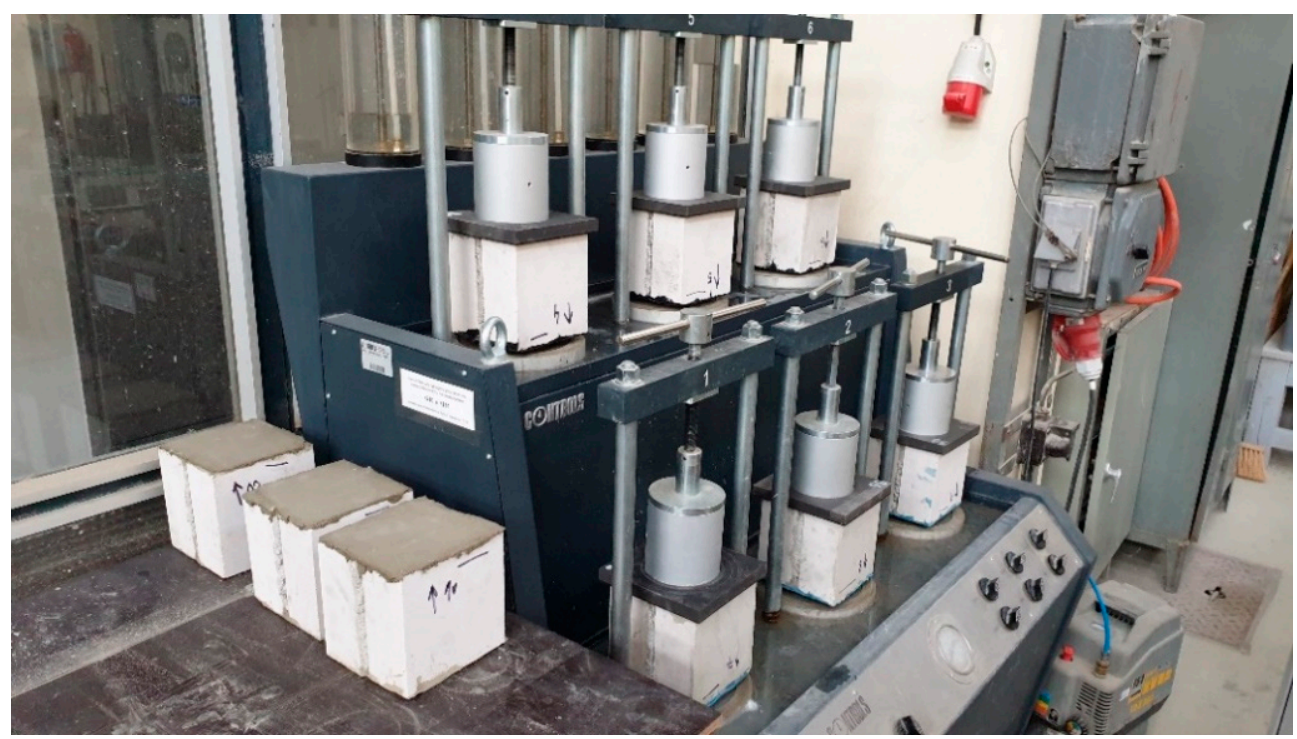

Figure 4. Water pressure test on the sets of specimens.

The tested sets of specimens were not designed for watertightness testing at a water pressure higher than $0.12 \mathrm{MPa}$. The reason was the method of applying stress (shear load) in the proposed test. The limitation was in the ultimate shear strength of the mortar in the joint. The common shear strength values of masonry (lime-sand bricks) with common cement mortar reach the value of approximately $0.15 \mathrm{MPa}$.

There is no need for the resistance to higher water pressures on real in situ masonry. In the case of a higher demand for resistance to pressurised water (deeper substructure), there is an obvious use of a reinforced concrete structure (the White Tank principle-in English-speaking countries and Die Weiße Wanne-in German-speaking countries).

\subsection{Main Study-Cohesion to Structures}

After performing the series of experiments listed in Sections 2.1 and 2.2, the potentiality of further testing to verify the adhesion of waterproofing screeds to various substrates of building materials was verified. The subject of the study was the influence of freeze-thaw cycles on the monitored mechanical properties.

The experiment included more than a hundred specimens (Table 1). All the specimens were created according to the initial model (Figure 5).

Four sets of specimens were prepared with different materials-ceramics, concrete, lime-sand and marl stone. All the test specimens were created according to the model as 108 cylinders with a diameter of $50 \mathrm{~mm}$ with a core bore. The bore was $8 \mathrm{~mm}$ in diameter and $30 \mathrm{~mm}$ deep.

The borehole was subsequently cleaned with compressed air. A degreased M8 threaded rod, $100 \mathrm{~mm}$ long, was glued into the bore. The threaded rod had to be degreased well (Figure 6). 
Table 1. Total set of specimens.

\begin{tabular}{|c|c|c|c|c|c|c|c|c|c|c|}
\hline \multirow[b]{2}{*}{ Ceramics } & \multirow{2}{*}{$\begin{array}{c}\begin{array}{c}\text { Boundary } \\
\text { Conditions }\end{array} \\
\text { Reference } \\
15 \text { freezing cycles } \\
30 \text { freezing cycles }\end{array}$} & \multicolumn{3}{|c|}{ Bitumen Screed } & \multicolumn{3}{|c|}{ Polymer Screed } & \multicolumn{3}{|c|}{ Silicate (Mineral) Screed } \\
\hline & & $\begin{array}{c}\text { spec. } 1 \\
\text { spec. } 10 \\
\text { spec. } 19\end{array}$ & $\begin{array}{l}\text { spec. } 2 \\
\text { spec. } 11 \\
\text { spec. } 20\end{array}$ & $\begin{array}{l}\text { spec. } 3 \\
\text { spec. } 12 \\
\text { spec. } 21\end{array}$ & $\begin{array}{l}\text { spec. } 4 \\
\text { spec. } 13 \\
\text { spec. } 22\end{array}$ & $\begin{array}{l}\text { spec. } 5 \\
\text { spec. } 14 \\
\text { spec. } 23\end{array}$ & $\begin{array}{l}\text { spec. } 6 \\
\text { spec. } 15 \\
\text { spec. } 24\end{array}$ & $\begin{array}{l}\text { spec. } 7 \\
\text { spec. } 16 \\
\text { spec. } 25\end{array}$ & $\begin{array}{l}\text { spec. } 8 \\
\text { spec. } 17 \\
\text { spec. } 26\end{array}$ & $\begin{array}{l}\text { spec. } 9 \\
\text { spec. } 18 \\
\text { spec. } 27\end{array}$ \\
\hline Concrete & $\begin{array}{c}\text { Reference } \\
15 \text { freezing cycles } \\
30 \text { freezing cycles }\end{array}$ & $\begin{array}{l}\text { spec. } 28 \\
\text { spec. } 37 \\
\text { spec. } 46\end{array}$ & $\begin{array}{l}\text { spec. } 29 \\
\text { spec. } 38 \\
\text { spec. } 47\end{array}$ & & & & & & & $\begin{array}{l}\text { spec. } 36 \\
\text { spec. } 45 \\
\text { spec. } 54\end{array}$ \\
\hline $\begin{array}{l}\text { Lime } \\
\text { sand }\end{array}$ & $\begin{array}{c}\text { Reference } \\
15 \text { freezing cycles } \\
30 \text { freezing cycles }\end{array}$ & $\begin{array}{l}\text { spec. } 55 \\
\text { spec. } 64 \\
\text { spec. } 73\end{array}$ & $\begin{array}{l}\text { spec. } 56 \\
\text { spec. } 65 \\
\text { spec. } 74\end{array}$ & $\begin{array}{l}\text { spec. } 57 \\
\text { spec. } 66 \\
\text { spec. } 75\end{array}$ & $\begin{array}{l}\text { spec. } 58 \\
\text { spec. } 67 \\
\text { spec. } 76\end{array}$ & $\begin{array}{l}\text { spec. } 59 \\
\text { spec. } 68 \\
\text { spec. } 77\end{array}$ & $\begin{array}{l}\text { spec. } 60 \\
\text { spec. } 69 \\
\text { spec. } 78\end{array}$ & $\begin{array}{l}\text { spec. } 61 \\
\text { spec. } 70 \\
\text { spec. } 79\end{array}$ & $\begin{array}{l}\text { spec. } 62 \\
\text { spec. } 71 \\
\text { spec. } 80\end{array}$ & $\begin{array}{l}\text { spec. } 63 \\
\text { spec. } 72 \\
\text { spec. } 81\end{array}$ \\
\hline Marl & $\begin{array}{c}\text { Reference } \\
15 \text { freezing cycles } \\
30 \text { freezing cycles }\end{array}$ & $\begin{array}{c}\text { spec. } 82 \\
\text { spec. } 91 \\
\text { spec. } 100\end{array}$ & $\begin{array}{c}\text { spec. } 83 \\
\text { spec. } 92 \\
\text { spec. } 101\end{array}$ & $\begin{array}{c}\text { spec. } 84 \\
\text { spec. } 93 \\
\text { spec. } 102\end{array}$ & $\begin{array}{c}\text { spec. } 85 \\
\text { spec. } 94 \\
\text { spec. } 103\end{array}$ & $\begin{array}{c}\text { spec. } 86 \\
\text { spec. } 95 \\
\text { spec. } 104\end{array}$ & $\begin{array}{c}\text { spec. } 87 \\
\text { spec. } 96 \\
\text { spec. } 105\end{array}$ & $\begin{array}{c}\text { spec. } 88 \\
\text { spec. } 97 \\
\text { spec. } 106\end{array}$ & $\begin{array}{c}\text { spec. } 89 \\
\text { spec. } 98 \\
\text { spec. } 107\end{array}$ & $\begin{array}{c}\text { spec. } 90 \\
\text { spec. } 99 \\
\text { spec. } 108\end{array}$ \\
\hline
\end{tabular}

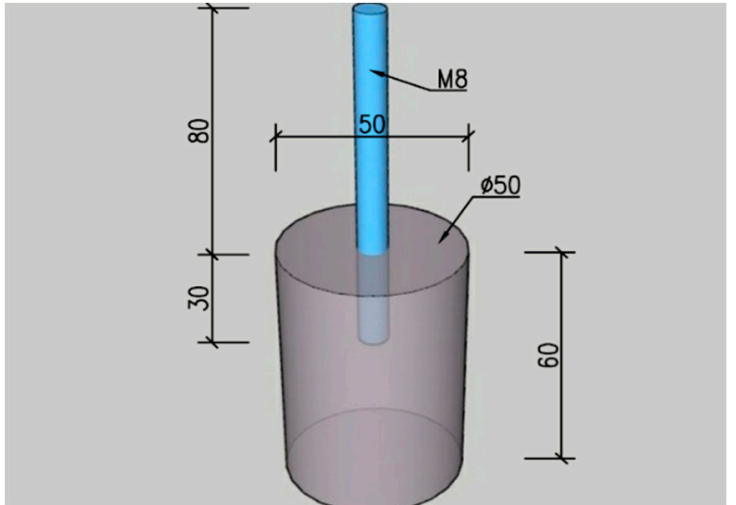

(a)

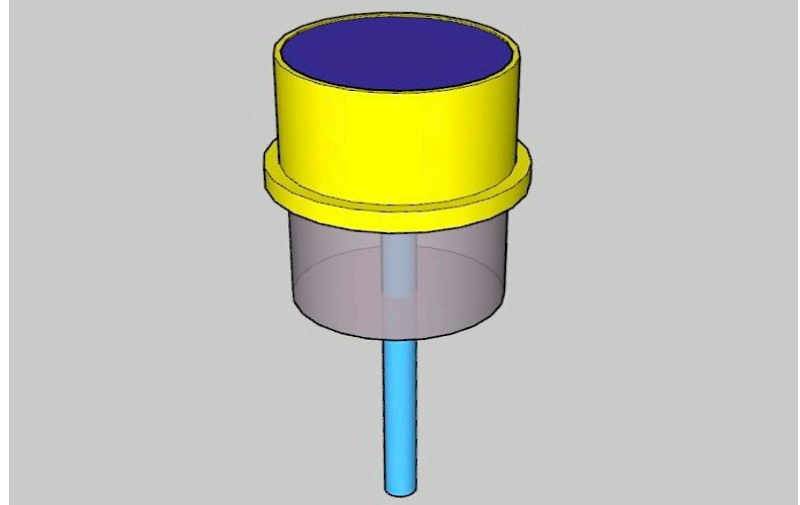

(b)

Figure 5. (a) Model of the specimen; (b) model of the prepared specimen with a delimiting ring and the applied waterproofing screed.

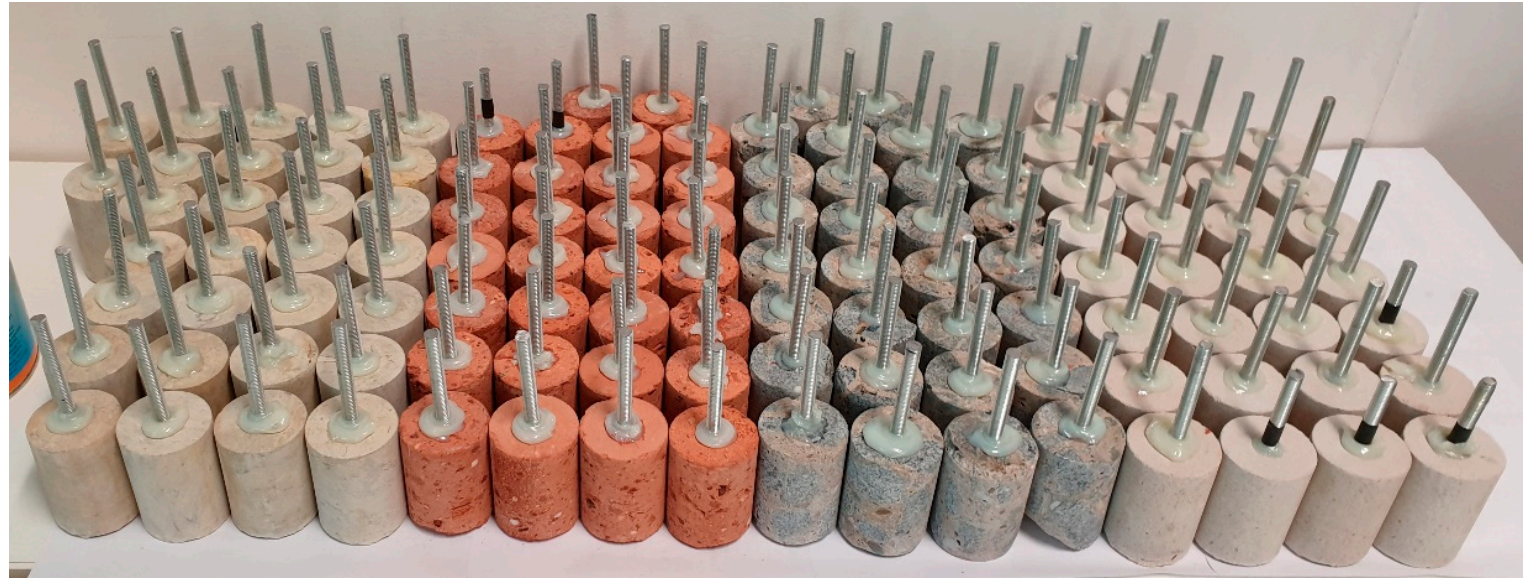

Figure 6. Assembly of all test specimens with glued threaded rods.

In the next step, the chipped edges of the cylinders on the side where the waterproofing screed would be applied had to be solved. The flat surface and the accurate thickness of the screed was achieved by help of polyvinyl-chloride (PVC) ring, which was fixed to cylinder during the application of the screed. Thus, the ring created a formwork for the subsequent application of the screed. 
Three types of waterproofing screeds (bitumen, polymer and silicate) were applied to the test specimens of each type of tested structures (Figure 7).

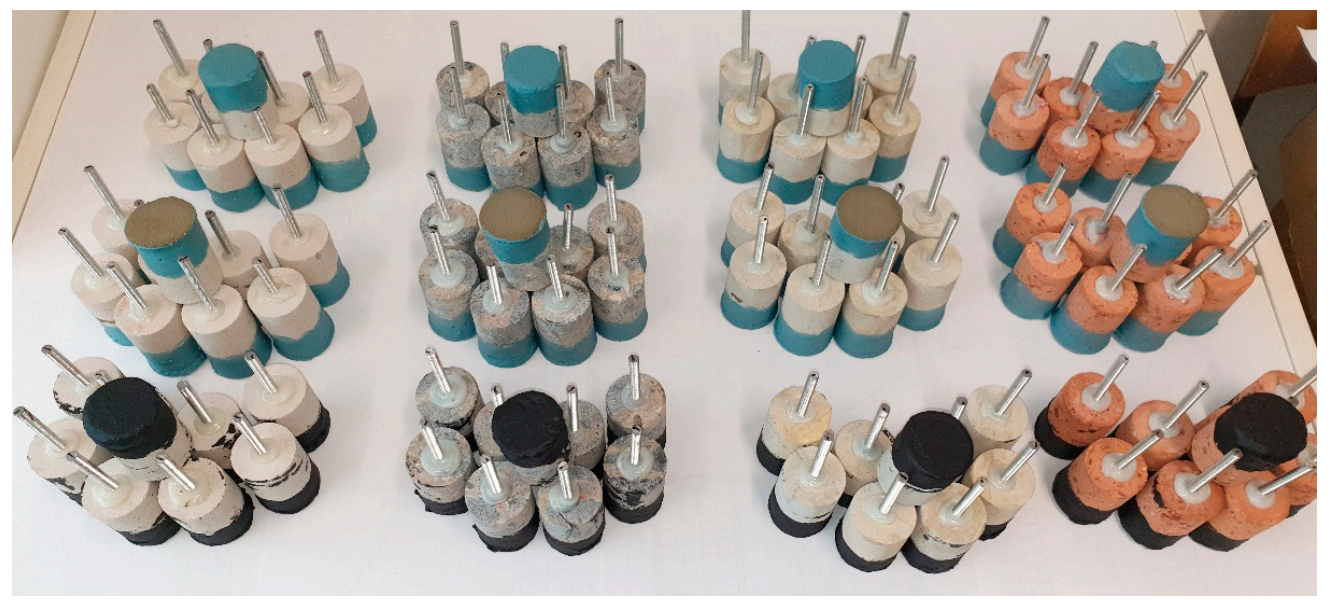

Figure 7. Finished set of specimens with the applied waterproofing screed.

Three sets of specimens were created, each set with different boundary conditions. Everything will be done three times to verify the accuracy of the measurement. The first set of specimens that will serve as a reference set will be placed indoors at a constant temperature and humidity. The second set was subjected to freezing and thawing.

The test specimens were immersed surface with a surface treatment in water at $(+20 \pm 3)^{\circ} \mathrm{C}$ for $6 \mathrm{~h}$, so that between the screed and the substrate is $10 \mathrm{~mm}$ below the water surface. The specimens were then removed and stored vertically in a freezing chamber at a temperature of $(-20 \pm 2)^{\circ} \mathrm{C}$ for $18 \mathrm{~h}$. Thus, one freeze-thaw cycle consisting of water immersion and following freezing takes $24 \mathrm{~h}$. The surface of the screeds was visually inspected after each cycle.

After the required number of cycles, the specimens are left to dry at an air temperature of $(+20 \pm 3)^{\circ} \mathrm{C}$ and a relative humidity of $(55 \pm 10) \%$ for at least 14 days. The method of freezing described above is inspired by the Czech national standard ČSN 732579 from 1981 [29].

A tear-off test disc with a diameter of $50 \mathrm{~mm}$ is glued to the hardened waterproofing screed with a two-component epoxy adhesive. The test disc is made of sheet metal $8 \mathrm{~mm}$ in thickness (Figure 8a). A threaded rod DN 10 is welded to the sheet metal. The weld is ground on the target from below. Thus, the grinding created a flat contact surface (Figure 8b).

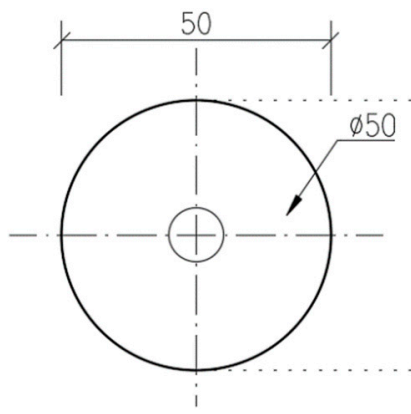

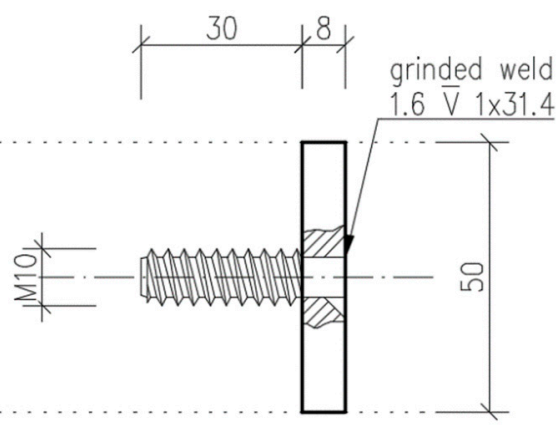

(a)

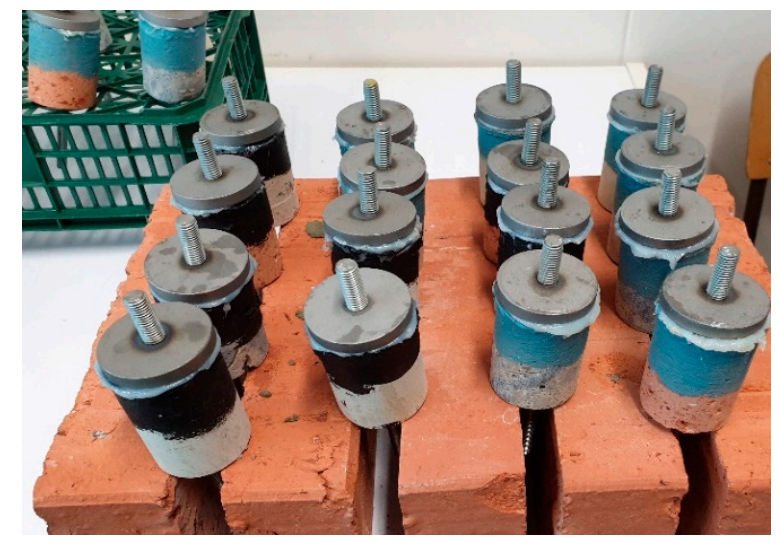

(b)

Figure 8. (a) Tear-off test disc target scheme; (b) gluing tear-off targets. 
During the tear-off tests, it was necessary to ensure the axial loading. The tension was exerted by a steel ring which is screwed onto the threaded rod. A similar fastening system was used on the opposite side (Figures 9 and 10).

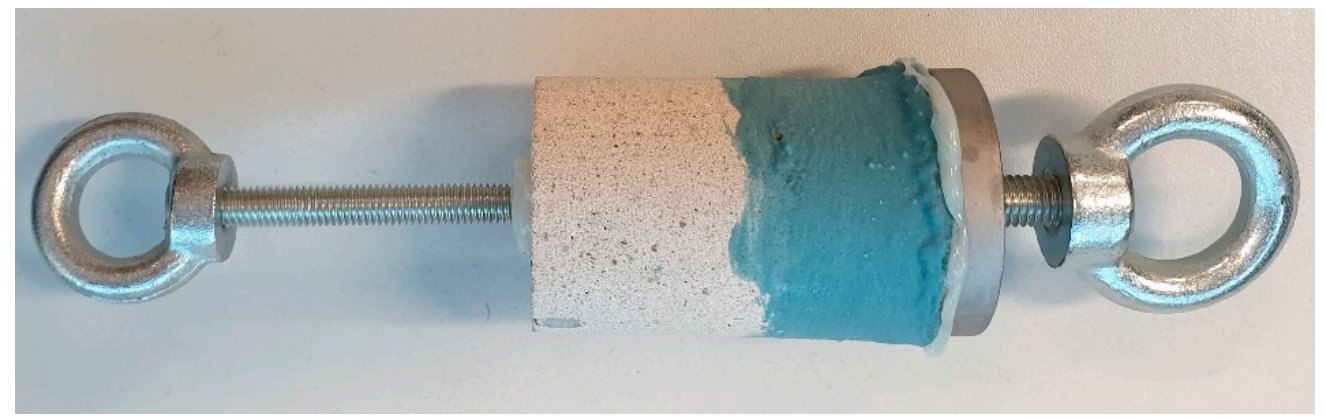

Figure 9. Detail of a test specimen with a glued target.

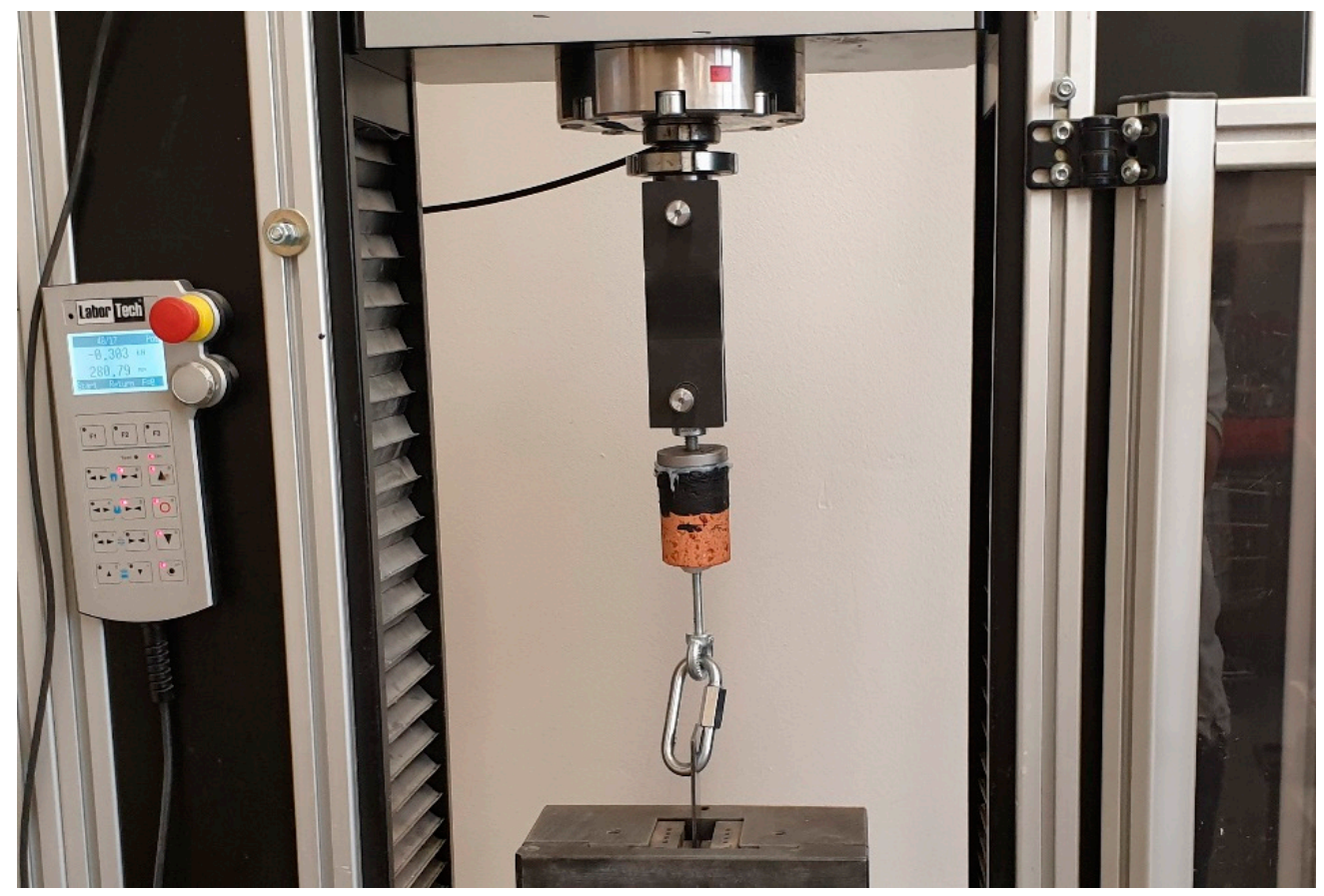

Figure 10. Test specimen prepared for the tear-off test.

Tear-off tests were performed with the electromechanical testing machine LabTest 4.100 ST1 (LaborTech s.r.o., Opava, Czech Republic). This testing machines made it possible to monitor and record the course of tensile stress in real time. The accuracy class is according to EN ISO 7500-1, ASTM E4.

\section{Results and Discussion}

\subsection{Basic Study-Water Pressure Test}

Each measurement was performed on three specimens so that the measured values could be averaged. The average weight gain values are presented in Table 2. 
Table 2. Average weight gain.

\begin{tabular}{lccccc}
\hline Water Pressure & $\mathbf{0 . 0 6} \mathbf{~ M P a}$ & \multicolumn{2}{c}{$\mathbf{0 . 1 2} \mathbf{~ M P a}$} & \multicolumn{2}{c}{$\mathbf{0 . 2 4} \mathbf{~ M P a}$} \\
\hline Time (h) & $\begin{array}{c}\text { after 5 h } \\
\text { (the reference specimen } \\
\text { fully saturated) }\end{array}$ & after 12 h & after 24 h & after 36 h & after 58 h \\
\hline \multicolumn{7}{c}{ Average Weight Gain (\%) } \\
Bituminous Screeds & 0.03 & - & - & - & - \\
Polymer Screeds & 0.05 & 0.03 & 0.03 & 0.06 & 0.11 \\
Silicate (Mineral) Screeds & 0.07 & 0.06 & 0.10 & 0.13 & 0.15 \\
\hline
\end{tabular}

The waterproofing ability of all types of tested screeds applied on all tested building structures was shown during the test. The maximum level of water pressure (reached in the last phase of loading) corresponded to $0.24 \mathrm{MPa}$ ( $24 \mathrm{~m}$ of hydrostatic pressure). The results verified the values in the technical data sheets of the manufacturers but there were some differences in their properties among each other. In the case of the reference specimen, there was a percentage weight gain of $4.02 \%$ in $5 \mathrm{~h}$. After $5 \mathrm{~h}$ of loading by water, the results manifested almost no effect on any of the tested screeds.

After $5 \mathrm{~h}$ and after increasing the water pressure to $0.12 \mathrm{MPa}$, the silicate (mineral) screeds gain weight and continue to increase until $58 \mathrm{~h}$. The weight gain was almost linear throughout the test (Figure 11). The weight gains also slowed down over time.

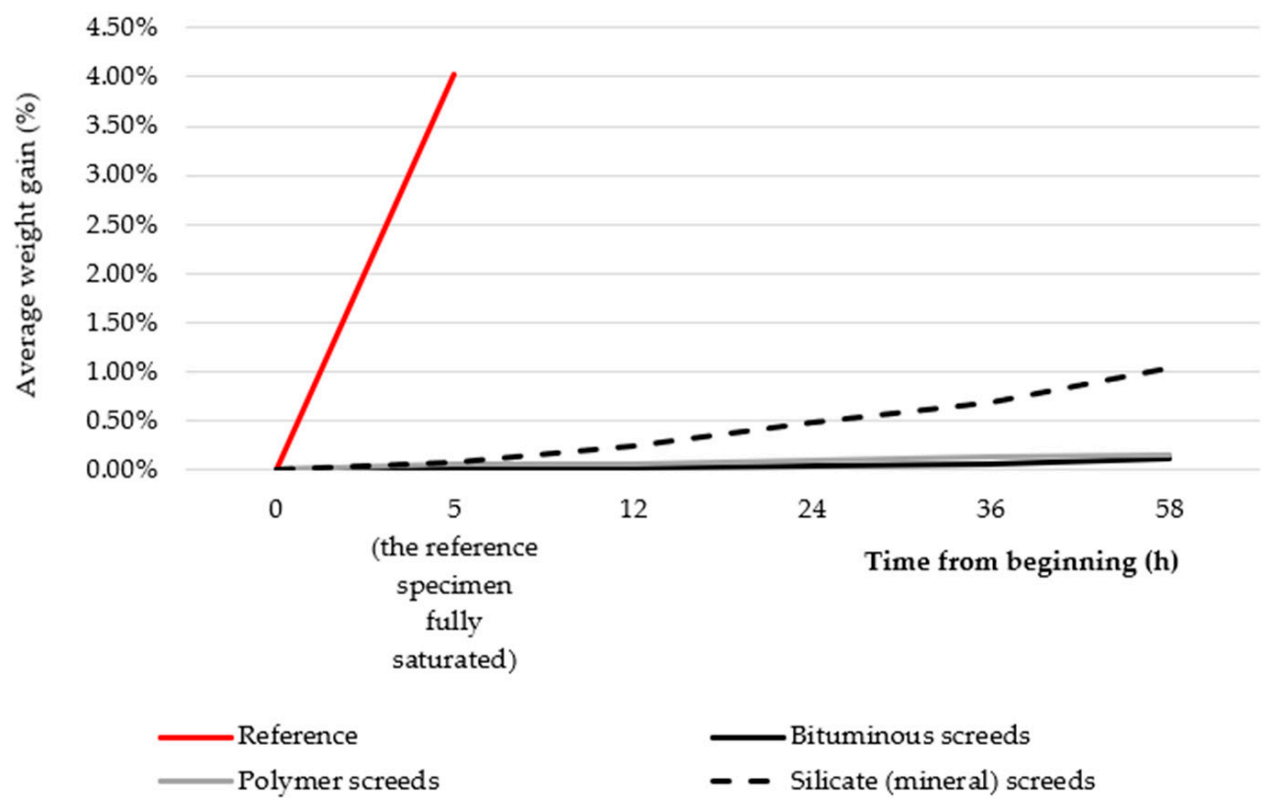

Figure 11. Change in weight during the time (in percentage).

The bitumen and polymer screeds had almost the same measured values throughout all the pressures tested. The weight gain was very small throughout the test. The bitumen and polymer screeds have a higher waterproofing effect compared to the silicate (mineral) screeds. The measured values of leakage were very small, and the waterproofing screeds can be considered (on common building structures at normal pressures) to be watertight.

\subsection{Additional "Masonry Test"-Influence of Joints}

The results of the water pressure test showed again (as in the case of separate bricks) that there was a big difference between the specimens with applied screeds and the specimens without any treatment. In the case of the reference specimens (without a 
screed), water began to penetrate through the mortar joints as well as the brick's sides just several minutes after the test was started (Figure 12). For the specimens with all types of applied screed, there was no leakage of water during the testing time-water had not penetrated through the bricks, nor through the joints. The results clearly confirmed that the waterproofing effect of the screed was not significantly influenced by the joints in masonry.

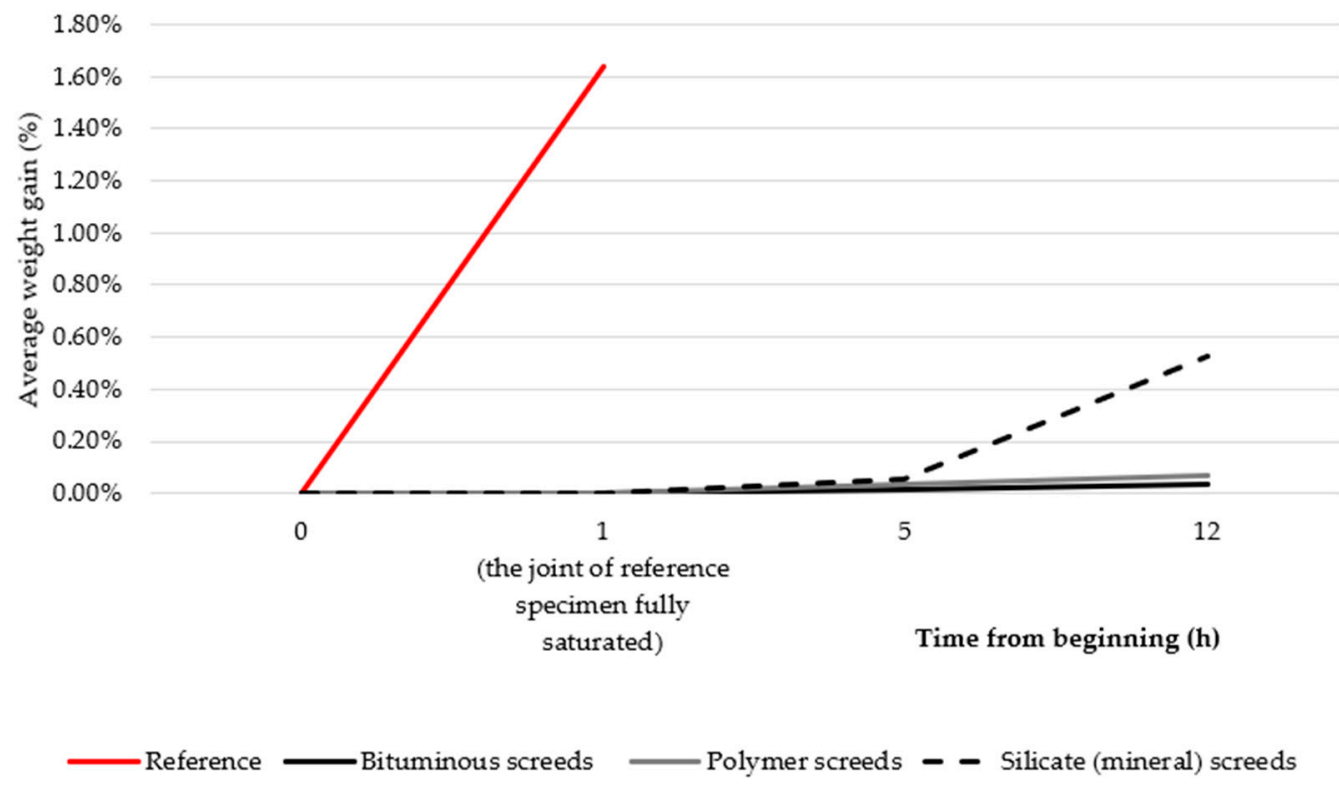

Figure 12. Change in weight during the time (in percentage).

\subsection{Main Study-Cohesion to Structures}

After the tear-off test, the type of failure was observed. The failure manifested itself at the screed-substrate interface. It can be called "an adhesive failure" (Figure 13b). In some cases, the screed itself was broken, which can be called "a cohesive failure" (Figure 14a).

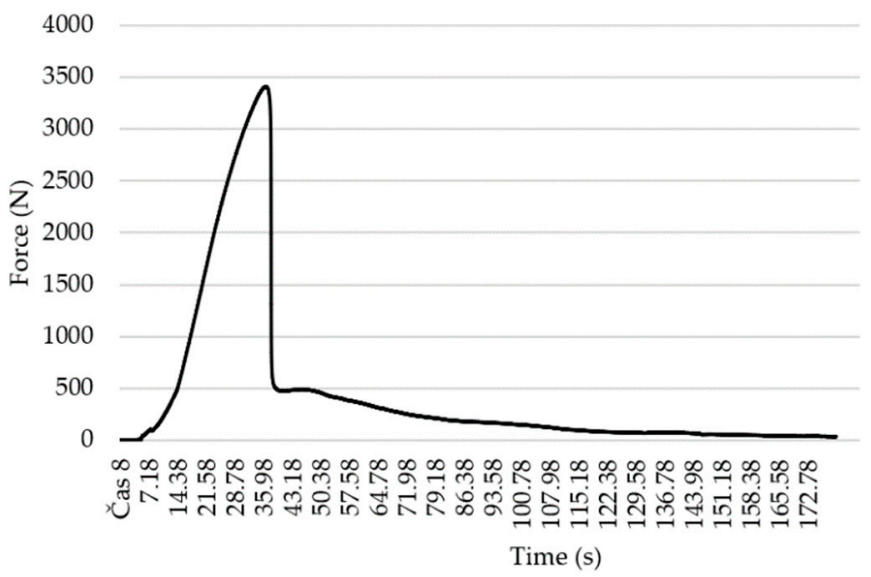

(a)

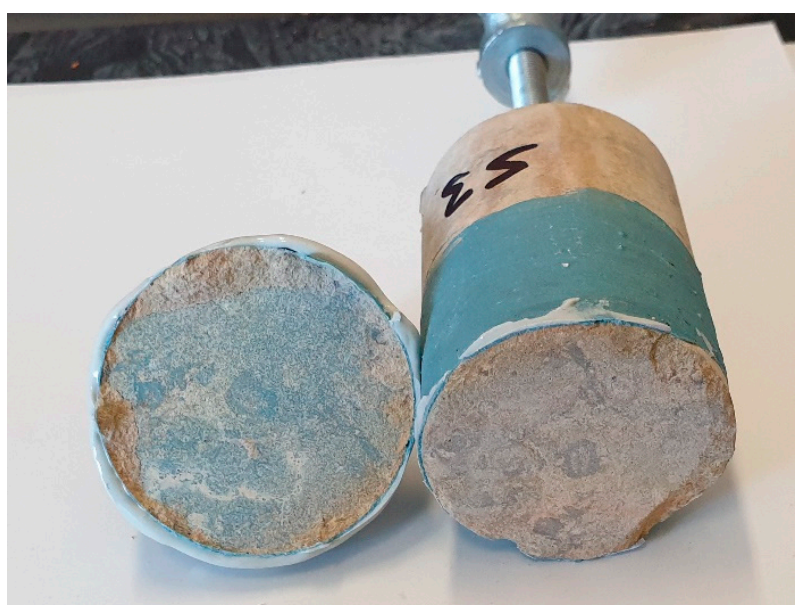

(b)

Figure 13. (a) Typical course of tensile force on a test specimen; (b) adhesive failure. 


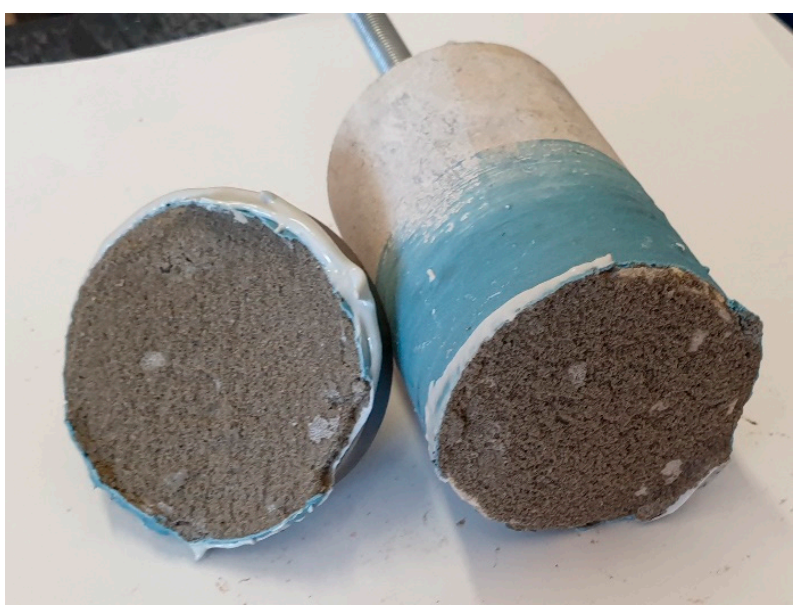

(a)

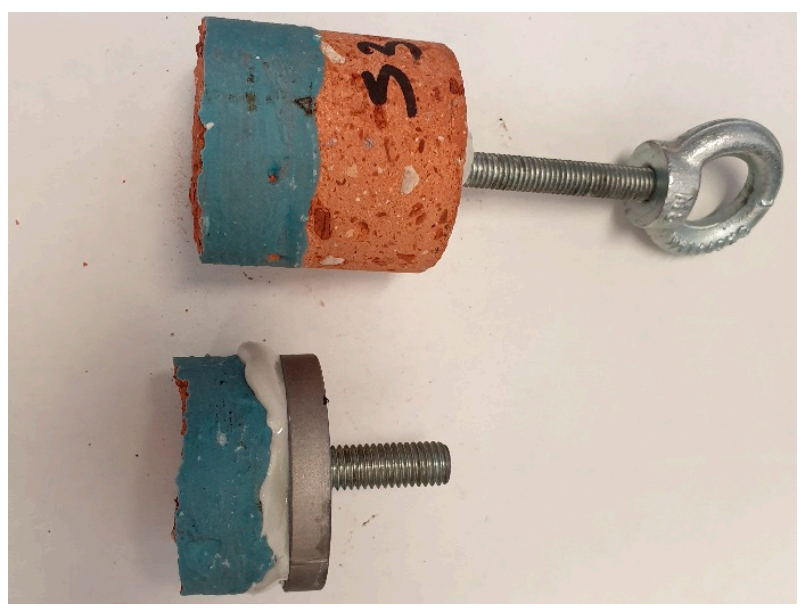

(b)

Figure 14. (a) Cohesive failure; (b) substrate failure.

In some cases, especially after several freezing cycles, the base material itself was broken. The substrate had not withstood the freezing cycles. In this case, the adhesion and the tensile strength of the screed are higher than the strength of the substrate (Figure 14b).

Figure 13a shows a typical record of the test. Specifically, it is Specimen No. 3-the silicate (mineral) screed on the marl stone after 15 freezing cycles.

From the total number of 108 specimens, 65 adhesive failures (60\%), 16 cohesive failures $(15 \%)$ and 26 cases of substrate damage $(25 \%)$ could be observed after the finish of the experiment.

\subsubsection{Results with the Substrate Influence}

The detailed results of the tear-off test are presented in (Figure 15), which represent the arithmetical mean of three measurements.

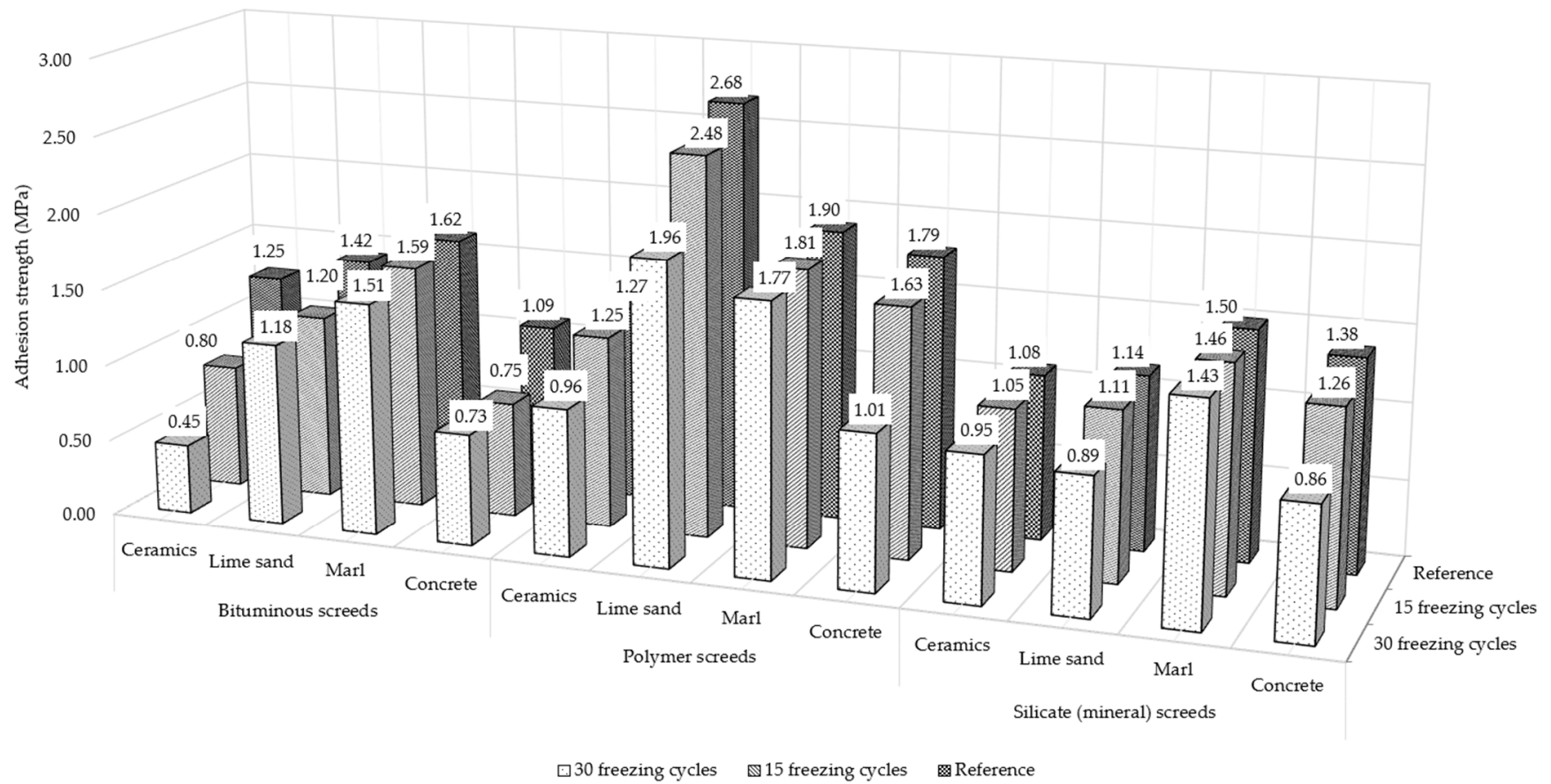

Figure 15. Results of the tear-off test, tensile strength. 
For comparison, it is interesting to express the values in percentages (Table 3).

Table 3. Residual strength in percentage.

\begin{tabular}{cccc}
\hline \multirow{2}{*}{ Type of the Screeds } & Type of Substrate & $\begin{array}{c}\text { After 15 Freezing } \\
\text { Cycles }\end{array}$ & $\begin{array}{c}\text { After 30 Freezing } \\
\text { Cycles }\end{array}$ \\
\hline \multirow{3}{*}{ Bituminous Screeds } & Ceramics & $64.0 \%$ & $36.3 \%$ \\
& Lime sand & $84.1 \%$ & $83.1 \%$ \\
& Marl & $97.8 \%$ & $93.0 \%$ \\
\multirow{2}{*}{ Polymer Screeds } & Concrete & $68.8 \%$ & $67.1 \%$ \\
& Ceramics & $98.1 \%$ & $75.4 \%$ \\
& Lime sand & $92.4 \%$ & $73.3 \%$ \\
& Marl & $95.1 \%$ & $93.1 \%$ \\
Silicate (Mineral) Screeds & Concrete & $90.9 \%$ & $56.5 \%$ \\
& Ceramics & $96.7 \%$ & $87.7 \%$ \\
& Lime sand & $96.9 \%$ & $77.9 \%$ \\
& Marl & $97.7 \%$ & $95.2 \%$ \\
\hline
\end{tabular}

The failure of the substrate manifested especially in the case of ceramic material. The ceramic shard probably lost the most of its strength during the freezing cycles, which indicate low freeze-thaw resistance of used ceramic bricks accompanied by cracks propagation. The decay of strength of the ceramic shard was evidenced especially in case of the bituminous screed. Thus, the adhesive strength of the waterproofing screed was higher than the tensile strength of the substrate material after freeze-thaw cycles. The measured values were retained mainly because the boundary conditions were the same for all examined waterproofing screeds.

Results-Bituminous Screeds

As mentioned above, in the case of bituminous screeds, the greatest damage in the ceramic specimens was caused due to the failure of the substrate. Therefore, the values measured on the ceramic shard cannot be considered as the adhesion of the screed. Thus, it can be assumed that the bitumen screed cohesion exceeds the tensile strength of the used ceramic. In the case of lime-sand bricks, marl stone and concrete, the values are already suitable for making a comparison of the adhesion, which was the goal of this experiment. The best cohesion and interaction can be observed on the marl substrate in the range of 1.62-1.51 MPa. In the experiment, the measured values were by about $20 \%$ higher than those for lime sand, $1.42-1.18 \mathrm{MPa}$, and by $45 \%$ higher than those for concrete, 1.09-0.73 MPa.

At the same time, the influence of the freezing cycles on the durability and adhesion of the bitumen screed is visible from Figures 16 and 17. Comparing the reference specimen and the tested specimen after 15 freezing cycles, there was a decay of adhesion to $84 \%$, and, after additional 15 cycles, the original strength had dropped to $81 \%$. Thus, the total loss between 15 and 30 cycles is marginal. The test results have shown that further freezing cycles already have a minimal effect on the overall adhesion. 


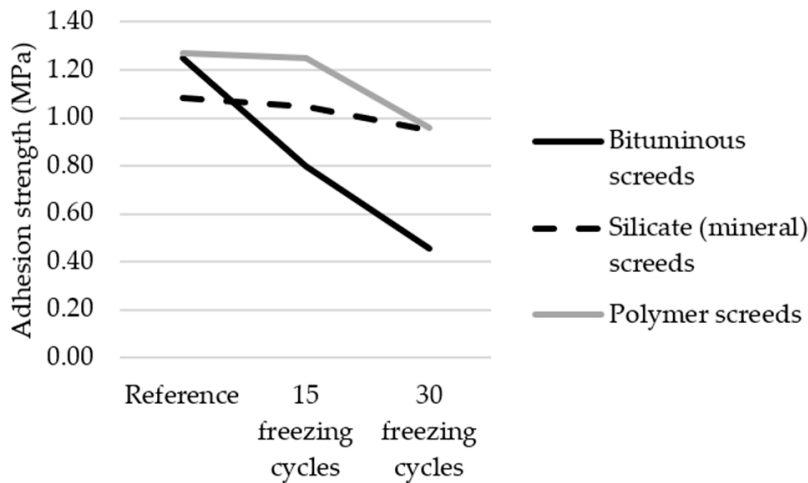

(a)

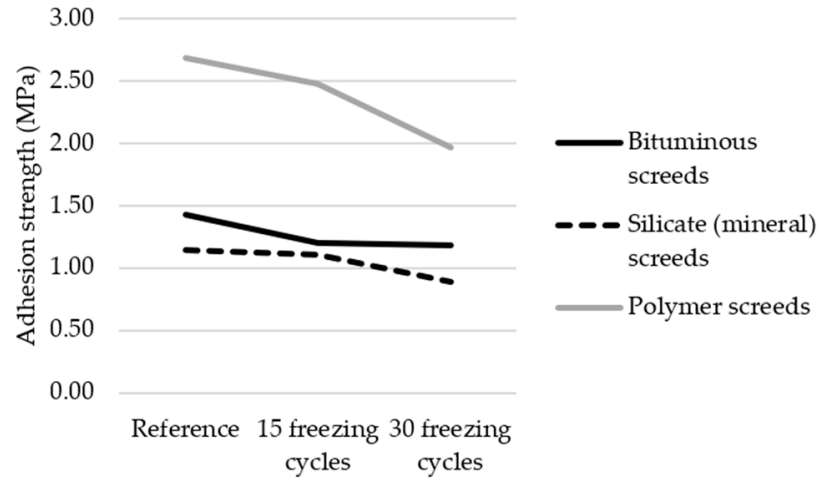

(b)

Figure 16. (a) Loss of strength—ceramics; (b) loss of strength-lime sand.

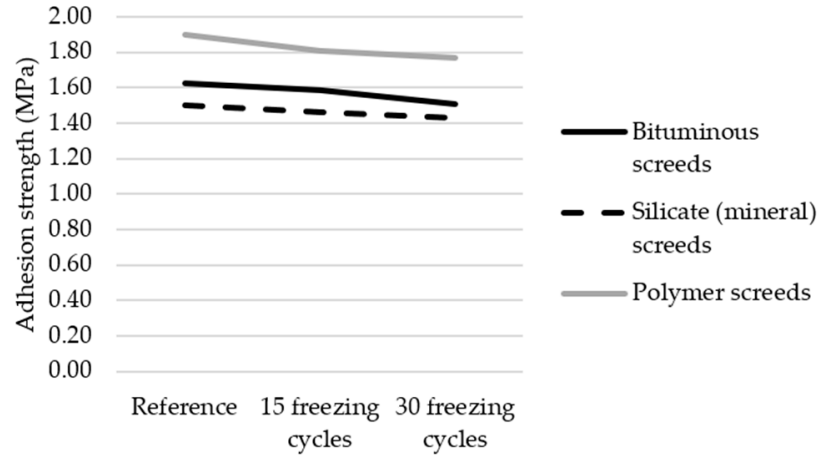

(a)

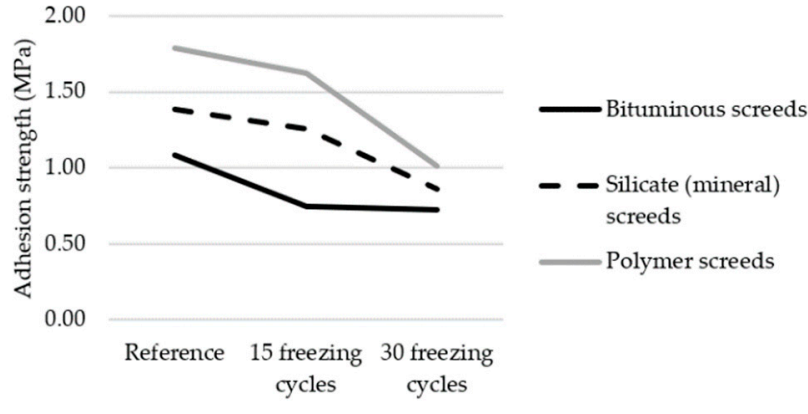

(b)

Figure 17. (a) Loss of strength-marl; (b) loss of strength-concrete.

\section{Results-Polymer Screeds}

In opposition to the bituminous screeds described above, polymers screeds have achieved higher adhesion to the substrate (Figures 16 and 17). The highest adhesion and interaction can be observed on the lime sand substrate in the range of 2.68-1.96 MPa. In the experiment, the measured values were by about $23 \%$ higher than those for marl, 1.9-1.77 MPa, by $38 \%$ higher than those for concrete, $1.79-1.01 \mathrm{MPa}$, and by $51 \%$ higher than those for ceramic material, 1.27-0.96 MPa.

The effect of the freezing cycles on the screed's adhesion is the most significant between 15 and 30 cycles. Here, the difference between bitumen and silicate (mineral) screeds can be observed. Comparing the reference specimen and the tested specimen after 15 freezing cycles, there was a loss of adhesion to $94 \%$, and, after another 15 cycles, the original strength had dropped to $75 \%$. Thus, the total loss between 15 and 30 cycles was $19 \%$. The results showed a significant effect of the number of freezing cycles on the adhesion to the substrate. On the other hand, the measured adhesion values after the cycles are performed are higher than the values of the other screeds for the reference specimens. Hence, it can be noted that the adhesion is sufficient for use in construction, often higher than the strength of the base material. The polymer screed has the lowest durability against freeze-thaw cycles (in comparison to the other tested screeds).

\section{Results-Silicate (Mineral) Screeds}

In $45 \%$ of the specimens, the screed structure was damaged during the test. This can be assessed as its biggest weakness compared to the other tested screeds. The test results have shown that the adhesion to the substrate is higher than the tensile strength of the 
screed (Figures 16 and 17). Hence, damaged specimens in such a way were excluded from the experiment evaluation.

In terms of adhesion, the tested mineral screed can be classified very close to the bituminous screeds.

The best adhesion and interaction can be observed on the marl substrate in the range of $1.50-1.43$ [MPa]. In the study, the measured values were by about $20 \%$ higher than those for concrete, $1.38-0.86 \mathrm{MPa}$, and by $28 \%$ higher than those for lime sand, 1.14-0.89 $\mathrm{MPa}$. The values of the ceramic substrate are very similar to lime sand. The maximal measured strength is by $29 \%$ higher than that of the ceramic material, 1.08-0.95 MPa. The influence of the substrate is the lowest of all tested screeds.

Regardless of the substrate, the effect of freezing cycles on mineral screeds is the most linear of all tested screeds. The decay of the adhesion of mineral screed is proportional to the number of freeze-thaw cycles. Comparing the reference specimen and the tested specimen after 15 freezing cycles, there was a loss of adhesion to $95 \%$, and, after another 15 cycles, the original strength had dropped to $80 \%$. Thus, the total loss between 15 and 30 cycles accounts for $20 \%$. The experiment showed the effect of the freezing cycles similar to that of the bitumen screeds, with the difference between 15 and 30 cycles, there is a further loss of strength. Thus, it can be noted that the next time the freezing is repeated, the strength will continue to decay over time.

\subsubsection{Results without the Substrate Influence}

For practical use in construction, it is interesting to place the measured values of individual screeds against each other without the influence of the substrate material. The above values were, therefore, averaged, and the result is an unbiased comparison of individual types of screeds (Table 4).

Table 4. Total adhesion strength and total residual strength after 30 freezing cycles.

\begin{tabular}{cccc}
\hline & \multicolumn{2}{c}{$\begin{array}{c}\text { Average Adhesion Strength without } \\
\text { the Influence of the Substrate (MPa) }\end{array}$} & $\begin{array}{c}\text { Average Residual Strength after } \\
\text { 30 Freezing Cycles without the Influence of } \\
\text { the Substrate (\%) }\end{array}$ \\
\hline Type of Screed & Reference & 15 Freezing Cycles & 30 Freezing Cycles \\
Bituminous Screeds & 1.35 & 1.08 & 0.97 \\
Polymer Screeds & 1.91 & 1.79 & 1.43 \\
Silicate (Mineral) Screeds & 1.28 & 1.22 & 1.03 \\
\hline
\end{tabular}

When comparing the overall tested screeds, it can be seen from Table 4 that the greatest total adhesion is achieved by polymer screeds, which, at the same time, have the lowest durability during the freezing cycles. Bitumen screeds and silicate (mineral) screeds are very similar in the total values. However, they differ in their ability to withstand freezing cycles over time. In the case of bitumen screeds, the first 15 freezing cycles have the greatest effect, and there is no significant loss of strength. In contrast to this, silicate (mineral) screeds have a linear decrease in tensile strength due to freezing (Figure 18).

According to the manufacturer's technical data sheets for the used screeds, the manufacturers declare a minimum strength of $0.5 \mathrm{MPa}$ for all types. All the tested screeds have manifested a greater adhesion strength even after 30 freezing cycles. 


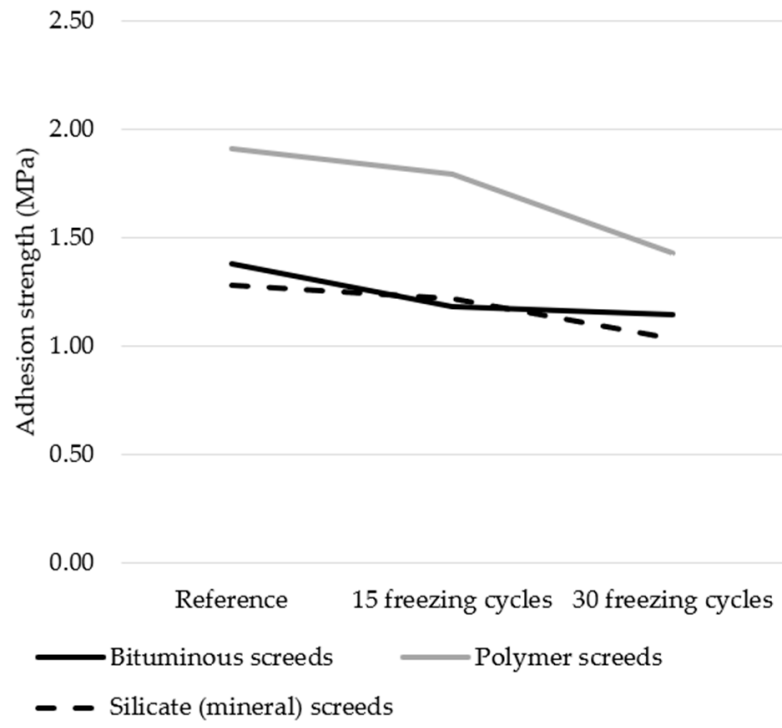

(a)

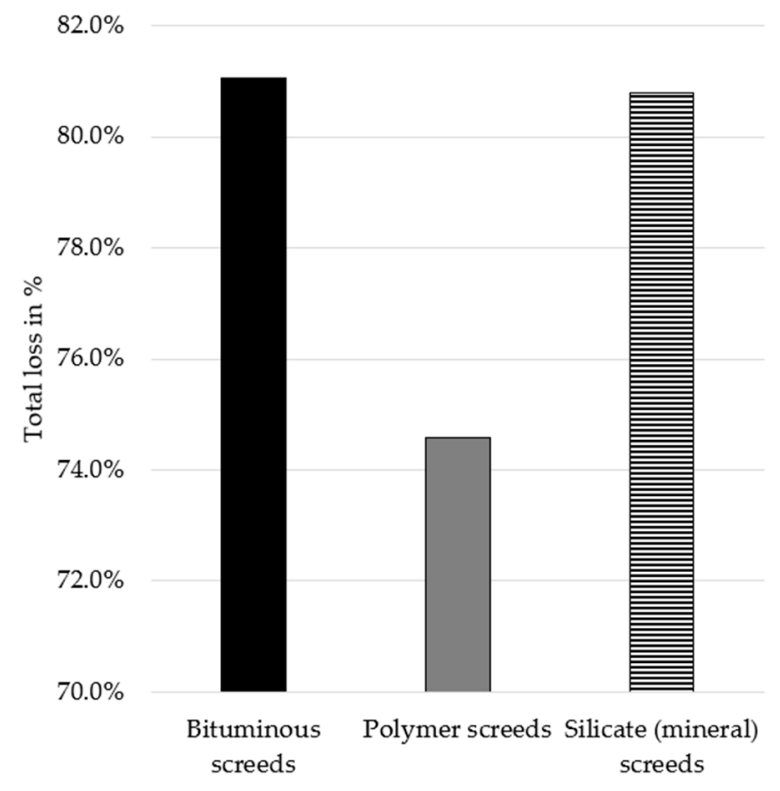

(b)

Figure 18. (a) Average adhesion strength without the influence of the substrate; (b) average residual strength after 30 freezing cycles without the influence of the substrate [\%].

\section{Conclusions}

The three most commonly used types of screeds (bitumen, polymer and silicate) on the four types of the most commonly used building structures (ceramics, concrete, lime sand and marl) were chosen for the study. The waterproofing ability of used screeds was evaluated in the experimental program in terms modified water permeability test. The cohesion was studied after the freeze-thaw exposure to take into consideration the durability aspects. The main conclusions could be summarised as follows:

- The suitable waterproofing ability of all types of the tested screeds applied on building materials was confirmed.

- All studied screeds resisted the water pressure of $0.12 \mathrm{MPa}$, however the mineral screed exhibited a seepage into the substrate material;

- The permeability testing performed on the "whole masonry" blocks declared no negative influence of the joints on the tightness of the studied screeds;

- The best cohesion exhibited the polymer screed, however concurrently achieved the highest decay of the cohesion during freeze-thaw cycling;

- The cohesion of the bitumen and mineral screed were very similar. While, the decay of mechanical properties of mineral screed was proportional to passed freeze-thaw cycles, the bitumen screed exhibited significant drop of the mechanical performance after 15 cycles, however following freeze-thaw exposure caused negligible deterioration.

The performed tests were carried out on masonry from new materials. The next question arises, whether the same results would be achieved in the case of mature masonry from a real structure. In the case of mature masonry, different degrees of chemical salinity due to the penetration of water over time can be observed. The action of chemically impure water (leakage through the masonry) can degrease the mechanical and physical properties of the screed. This will be the subject of a further study conducted in the future.

Author Contributions: Conceptualisation, M.N. and J.P.; methodology, M.N.; investigation, M.N., J.P. and P.R.; writing—original draft preparation, M.N.; writing—review and editing, P.R.; supervision, J.P. and P.R.; project administration, J.P. All authors have read and agreed to the published version of the manuscript. 
Funding: This research was funded by CTU in Prague, grant number SGS19/145/OHK1/3T/11.

Institutional Review Board Statement: Not applicable.

Informed Consent Statement: Not applicable.

Conflicts of Interest: The authors declare no conflict of interest.

\section{References}

1. Kubal, M. Construction Waterproofing Handbook, 2nd ed.; McGraw-Hill Publishing: New York, NY, USA, 2008.

2. Chew, M.Y.L.; De Silva, N. Benchmarks to Minimize Water Leakages in Basements. Struct. Surv. 2003, 21, 131-145. [CrossRef]

3. Larisch, M. Modern Concrete Technology and Placement Methods and Their Influence on Waterproofing Performance of Diaphragm Walls. In Proceedings of the New Zealand Concrete Industry Conference 2016, Auckland, New Zealand, 6-8 October 2016.

4. Pazderka, J. Concrete with Crystalline Admixture for Ventilated Tunnel against Moisture. Key Eng. Mater. 2016, 677, 108-113. [CrossRef]

5. Dao, V.; Dux, P.; Morris, P.H.; Carse, A.H. Performance of Permeability-reducing Admixtures in Marine Concrete Structures. Aci. Mater. J. 2010, 107, 291-296.

6. Furuya, T.; Iwasa, T.; Sasajima, Y. An Effective and Eternal Maintenance Method for Concrete Tunnel Structures. Tunn. Struct. 1998, 78, 439-447.

7. Zhu, K.; He, X.; Quan, Y.; Zhong, W.; Zhang, K. Application of Non-curing Rubber Asphalt Screed in Waterproofing of Shield Tunnel Segment Joints in Water-rich Stratum. Mod. Tunn. Tech. 2019, 56, 201-205. [CrossRef]

8. Kho, C.; Tan, S.C.; Kog, Y.C. A Strategy for Waterproofing of Underground Structures. Underground Singapore 2014, Singapore, 25 September 2014. Available online: https: / / docplayer.net/29928088-Underground-singapore-2014-day-1-25-th-septemberthursday-furama-riverfront-hotel.html (accessed on 29 October 2021).

9. Martin, K. Flexible Plastics Sheets for Waterproofing. Build. Forum. 1970, 2, 109.

10. Lim, S.; Kawashima, S. Mechanisms Underlying Crystalline Waterproofing Through Microstructural and Phase Characterization. J. Mater. Civ. Eng. 2019, 31, 9. [CrossRef]

11. Song, S.; Xue, X.; Li, Y.; Yang, J.; He, Z.; Shen, S.; Jiang, L.; Zhang, W.; Xu, L.; Zhang, H. Experimental Exploration of the WaterProofing Mechanism of Inorganic Sodium Silicate-based Concrete Sealers. Constr. Build. Mater. 2016, 104, 276-283. [CrossRef]

12. Wong, I.H. Experience with Waterproofness of Basements Constructed of Concrete Diaphragm Walls in Singapore. Tunn. Undergr. Space Technol. 1997, 12, 491-495. [CrossRef]

13. Bochen, J. Weathering Effects on Physical-chemical Properties of External Plaster Mortars Exposed to Different Environments. Constr. Build. Mater. 2015, 79, 192-206. [CrossRef]

14. WTA. Merkblatt 4-6-05 Wissenschaftlich-Technische Arbeitsgemeinschaft für Bauwerkserhaltung und Denkmalpflege e.V.; Fraunhofer IRB Verlag: Stuttgart, Deutschland, 2005; ISBN 978-3-8167-6996-5.

15. DIN 18195-1:2000-08. Water-Proofing of Buildings-Part 1: Principles, Definitions, Attribution of Waterproofing Types, $2000-08$. Available online: https:/ /www.din.de/en/getting-involved/standards-committees/nabau/publications/wdc-beuth:din21: 272715755 (accessed on 29 October 2021).

16. Kaya, D.; Topal, A.; Gupta, J.; McNally, T. Aging Effects on the Composition and Thermal Properties of Styrene-butadiene-styrene (SBS) Modified Bitumen. Constr. Build. Mater. 2020, 235, 117450. [CrossRef]

17. He, Y.H.; Cao, Z.L.; Liu, Z.Y.; Li, J.T.; Yu, J.Y.; Ge, Y.Y. Influence of Heat and Ultraviolet Aging on the Structure and Properties of High Dosage SBS Modified Bitumen for Waterproof. Constr. Build. Mater. 2021, 287, 122986. [CrossRef]

18. Zheng, C.F.; Xu, J.P.; Zhang, T.; Tan, J.G. Study on the Microscopic Damage of Porous Asphalt Mixture Under the Combined Action of Hydrodynamic Pressure and Ice Crystal Frost Heave. Constr. Build. Mater. 2021, 303, 124489. [CrossRef]

19. Bader, T.; Waldner, B.J.; Unterberger, S.H.; Lackner, R. On the Performance of Film Formers Versus Penetrants as Water-repellent Treatment of High-performance Concrete (HPC) Surfaces. Constr. Build. Mater. 2019, 203, 481-490. [CrossRef]

20. Kim, J.; Kitagaki, R. Chemical Properties and Mass Transfer Resistance of Mortar Surface Modified with Silicate-based Surface Impregnant. Constr. Build. Mater. 2020, 262, 120806. [CrossRef]

21. Chang, J.; Li, W.Z.; Wang, D.; Zhang, Y.Y. Effect of Silicate Modulus on Tensile Properties and Microstructure of Waterproof Coating Based on Polymer and Sodium Silicate-activated GGBS. Constr. Build. Mater. 2020, 252, 119056. [CrossRef]

22. Rahman, M.; Chamberlain, D. Performance of Crystalline Hydrophobic in Wet Concrete Protection. J. Mater. Civ. Eng. 2017, 29, 04017008. [CrossRef]

23. Almusallam, A.; Khan, F.; Dulaijan, S.; Al-Amoudi, O. Effectiveness of Surface Screeds in Improving Concrete Durability. Cem. Concr. Compos. 2003, 25, 473-481. [CrossRef]

24. Scancella, R.J. Use of Xypex Admixture to Concrete as an Inhibitor to Reinforcement Steel Corrosion. In Proceedings of the Materials Engineering Conference, Washington, DC, USA, 10-14 November 1996; Volume 2, pp. 1276-1280.

25. Chang, S.H.; Kang, T.H.; Choi, S.W.; Lee, C.; Hwang, G.S.; Choi, M.S. An Experimental Study on Fundamental Properties of A Sprayable Waterproofing Membrane. Tunn. Undergr. Space 2016, 26, 220-234. [CrossRef]

26. Pan, X.Y.; Shi, Z.G.; Shi, C.J.; Ling, T.C.; Li, N. A Review on Surface Treatment for Concrete-Part 2: Performance. Constr. Build. Mater. 2017, 133, 81-90. [CrossRef] 
27. Chatterji, S. Aspects of the Freezing Process in a Porous Material-Water System: Part 1. Freezing and the Properties of Water and Ice. Cem. Concr. Res. 1999, 29, 627-630. [CrossRef]

28. Klovas, A.; Dauksys, M.; Ciuprovaite, G. Frost Resistance of Concrete Surfaces Coated with Waterproofing Materials. In Proceedings of the AIP Conference Proceedings, Fethiye, Turkey, 24-27 April 2015; Volume 1653, p. 020060. [CrossRef]

29. ČSN 73 2579:1981-Test for Frost Resistance of Surface Finish of Building Structures, 1981-04. Available online: http:// csnonlinefirmy.agentura-cas.cz/html_nahledy/73/32733/32733_nahled.htm (accessed on 29 October 2021). 